\title{
Research on the Development of College Teachers' Practical Ability from the Perspective of Teachers' Professional Development
}

\author{
Hongchang Wang \\ Jilin Agricultural University, Changchun 130118, China.
}

\begin{abstract}
The practice ability of university teachers, especially young teachers in our country is generally low, so it is difficult for teachers to be competent for the task of cultivating the students' good practical ability. It is mainly displayed in the shortcomings in teaching practical ability, independent development ability, scientific research ability and ability to participate in the enterprise practice and so on. In order to completely reverse this situation, it is necessary to further update the concept of education, strengthen the awareness of practice. Through a series of measures like making a training plan to establish training mechanism, promote the cooperation between researchers and hiring part-time teachers, and comprehensively improve the practice ability of College teachers. In the meanwhile, it is necessary to give full play to the role of policy orientation, such as to reform the current teachers title evaluation system, establish an effective assessment and incentive mechanism, and introduce policies and regulations to promote the cooperation of production, teaching and research, and effectively promote the development of teachers' practical ability in Colleges and universities.
\end{abstract}

Keywords: practical ability; school-enterprise cooperation; production; teaching; and research cooperation; policy and security.

\section{Introduction}

One of the important tasks of talents cultivation of Colleges and universities is to cultivate a high-level, professional skills and technical personnel with strong practical ability, and they have learning ability, practical ability and the innovative ability, and also the training of practical ability for College students to use knowledge to solve the problem. The realization of the goal of training is largely related to the practical level and the comprehensive quality of the professional teachers. Teachers without practical experience cannot cultivate students with practical ability, so the improvement of teachers' practical ability is the key to ensure the quality of practice teaching [1].

From the point of view of the present situation of China's higher education, the cultivation of students' practical ability is still the weakest link of talent training in Colleges and universities. The practical ability of College students in our country is generally low, cannot adapt to the actual demand of society of senior specialized talents, so it is difficult to achieve the goal of training innovative talents with high quality. There are many factors that cause this problem, like restrictions on the internal and external practice teaching conditions, the influences of the old personnel training system, the traditional education concepts and ideas and so on. However, it is a very important reason that teachers in Colleges and universities in China, especially the young teachers' practical ability and the whole level is not high [2]. Therefore, in order to fundamentally solve this problem and improve the quality of practice teaching, we must put the focus on the teachers and take the teacher team as a fundamental guarantee to improve the quality of practice teaching. We must speed up the cultivation of teachers' practical ability and strive to build a high-quality teaching staff team with excellent theoretical level and rich practical experience.

\section{Present Situation of College Teachers' Practical Ability in China}

Taking the teachers of universities in China as the object, through a questionnaire survey, understand the development situation of new College teachers' practical ability, and then puts forward some countermeasures and suggestions. Researchers randomly selected 1000 teachers from 
20 universities in our country as the research object, and carried out a questionnaire survey. Among them, 954 valid questionnaires were collected and analyzed [3].

\subsection{Analysis on Teachers' Teaching Practice Ability}

Teachers' teaching practice ability is the foundation of all teachers' practical ability, clearly and accurately explaining the basic knowledge, basic theory, and obvious highlight; it can arrange the teaching content effectively, reasonably select the teaching materials, and integrate the academic achievements into the teaching content; and closely link the knowledge explanation and improvement of the students' practical ability; always encourage students and stimulate students' independent thinking and research ability; be good at finding the reasons of classroom problems, and try to find solutions; often communicate with colleagues and find their shortcomings in teaching and improve classroom teaching effect and often reflect on it, which is conducive to personal and professional growth.

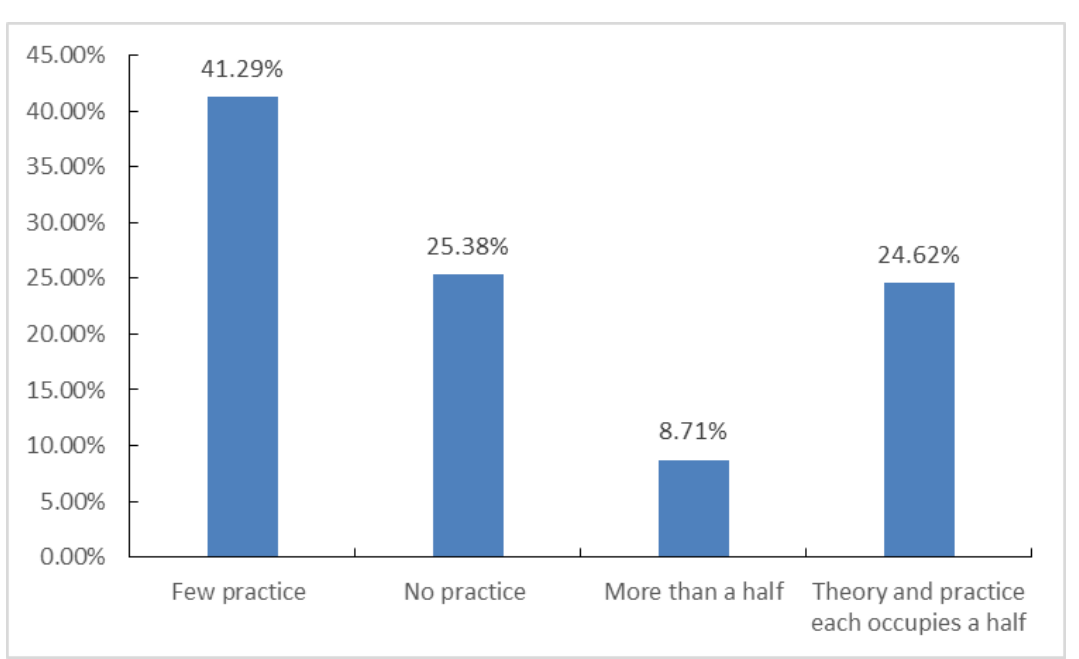

Figure 1 The proportion of practice teaching about the theory course in the teaching process

From Figure 1, we can see that the teachers in the teaching process, practice course teaching accounted for more than a half of theory teaching is only $8.71 \%$, the proportion of the number of teachers that occupy half in both theory and practice is $24.62 \%$, and a small amount of practice and no practice were as high as $41.29 \%$ and $25.38 \%$. It is obviously that the time for the teacher guiding students to practice in the classroom is little.

\subsection{Analysis on Teachers' Self-development Ability}

Self-development consciousness is the inner driving force for the development of teachers, and the ability of independent development is a necessary quality of teachers in newly built local Colleges. Only by promoting the ability of teachers' self-initiative development can we improve the quality of College education and guarantee the status of College education. At present, the teaching practice ability of College teachers in our country is slightly in the middle and upper level, which needs to be further improved.

\subsection{Analysis on Teachers' Scientific Research Ability}

Teachers' scientific research ability is not only the need of teaching and educating people, but also the requirement of direct service to the social development. At the same time, it is also a sign of the characteristics of the new local undergraduate Colleges and universities (Figure 2 and Figure 3). 


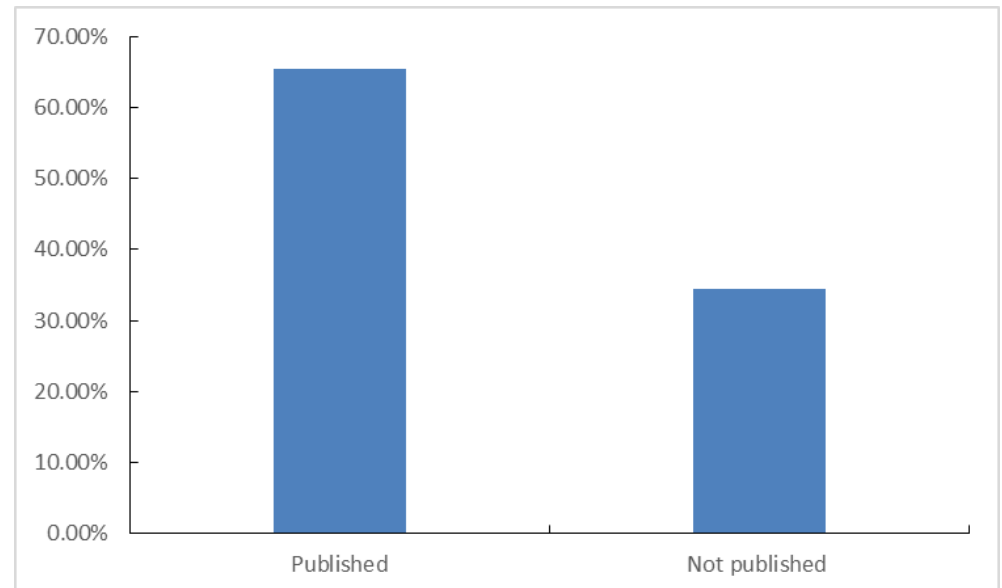

Figure 2 Has published educational scientific research papers or not

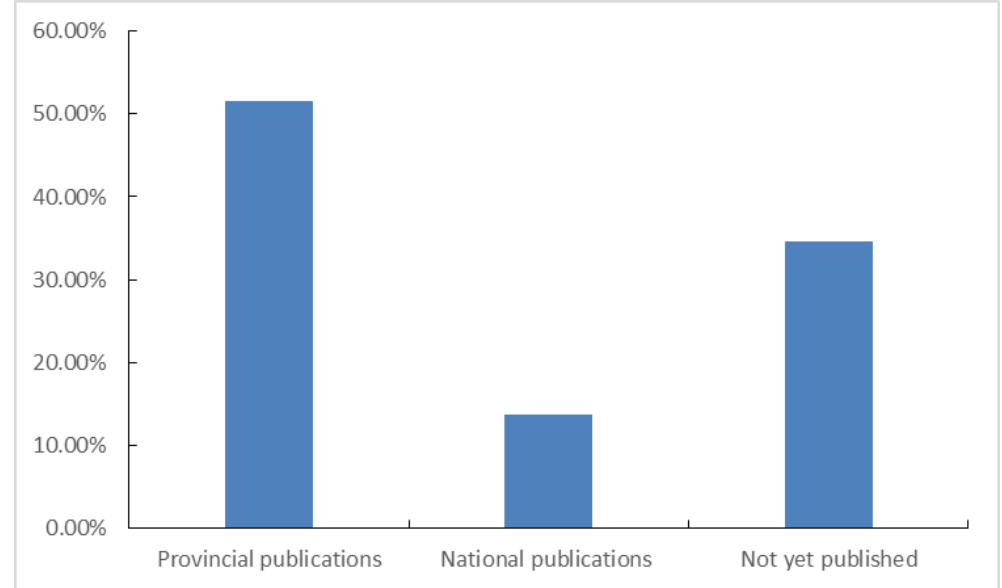

Figure 3 The level of journals published

\subsection{Analysis on Teachers' Participation in Enterprise's Practical Ability}

The teaching and scientific research in Colleges and universities should take into account the actual needs of the community (Figure 4). As a matter of fact, teachers' participation in enterprise practice is the essential embodiment of Colleges serving the society [4].

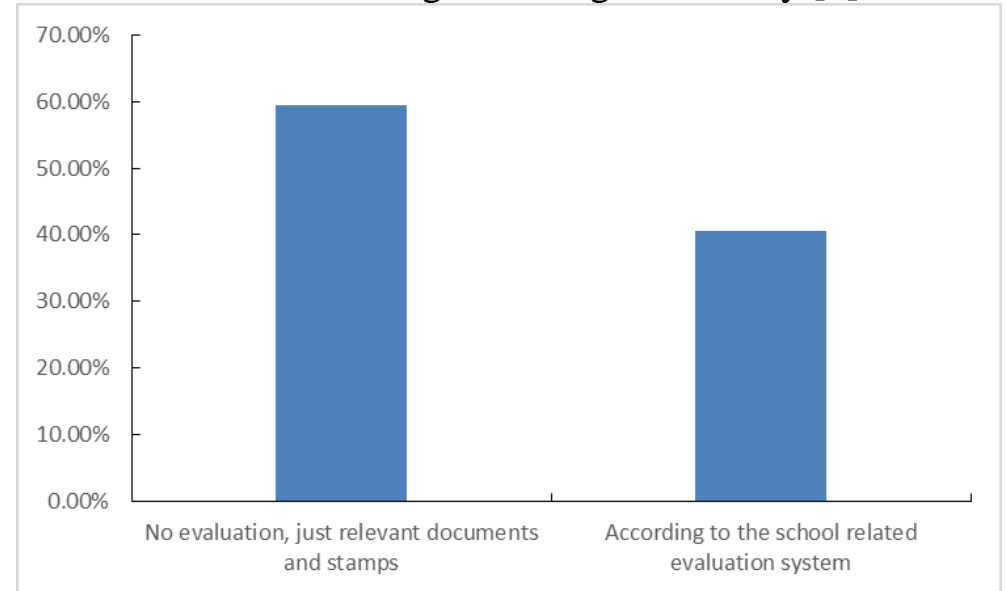

Figure 4 How to evaluate the effectiveness of teachers' enterprise practice

\section{Ways of Promoting the Development of College Teachers' Practical Ability in Colleges and Universities}

Improving College teachers' practical ability is a fundamental work to comprehensively improve the quality of higher education. It is also an important strategic task for the construction of College teachers' team. It is not only the inner demand of for Colleges and universities to achieve personnel 
training, scientific research, social services and cultural inheritance and innovation, but also the practical needs of transferring the great powers of higher education to the strong part of higher education. Therefore, it needs for education administrative departments, Colleges and universities, and the community to seriously study and jointly solve the issue of this era of College teachers' practical ability cultivation.

\subsection{Introduce Teachers from a Variety of Channels in Different Aspects}

Graduate students and doctoral students introduced from Colleges and universities, although they have a strong theoretical knowledge, they are rather insufficient in in practice skills, which can adapt to the teaching requirements only through the practice ability training, so they are more suitable for talent reserve resources in a school, conducive to the school's long-term development. Schools need some teachers who have practical experience to undertake the task of teaching, and introduction of teachers from various channel is an important way to solve this problem.

Absorb outstanding professionals in industries and enterprises who have practical experience and practical ability to teacher in the school. They master the latest industry information, have new knowledge and new technology of industries, which is difficult to obtain in a short period of time [5]. For excellent technical personnel of enterprises, learning ability is generally stronger than others. After introducing those into the school, through all aspects of teaching and training, let them have a solid theoretical foundation and rich practical teaching ability, and thus they are bound to be competent for the job of teaching.

Introducing talent from the enterprise can also avoid the aging of practical knowledge so that the school's teaching can keep up with the development requirements of the industry. The talents introduced by enterprises can also cultivate other teachers who are weak in practical skills, playing the role of "transferring, helping, and guiding", to promote the improvement of teachers' overall practical ability.

\subsection{Colleges Cooperate with Enterprises to Improve Teachers' Practical Ability}

Establish a stable off-campus practice base, take a long-term cooperation with enterprises, make use of the personnel training mode of school-enterprise cooperation, and use social resources to improve the students' practical skills. In the cultivation of teachers' practical ability, we can also make full use of these off-campus practice base to improve teachers' practical ability. Schools employ experts with rich experience in enterprises to the school to give professional seminars, communicate with teachers, enrich the teachers' professional knowledge, and improve teachers' practical ability. School can also request the professional and technical personnel in the company to proceed training practice for teachers, comprehensively improving teachers' practical teaching ability. At the same time, the school regularly send teachers to practice base for business practice or hangs duty exercise, directly contacting with the actual work, practice while learning master the latest technology and information management, and introduce the industry's latest achievements into teaching, which for the teachers who have no experience is the most effective way to improve the practical teaching ability.

\subsection{Make Development Plan and Establish Training Mechanism}

In the developing process of education course in our country, the requirement of the practical ability is generally ignored. Teacher troop construction plan also generally lack the content of teachers' practical ability cultivation and training. In recent years, Colleges and universities have established the center for faculty development (CPD or CFD), only for the training of education teaching ability, paying less attention to the development of teachers' practical ability, but in fact the practice ability of College teachers is also directly related to their teaching ability. Therefore, we must as soon as possible reverse this situation and re-define teachers' ability and quality structure under the new situation of College [6]. It is also necessary to refer to the agenda on the development of teachers' practical ability, study and formulate long-term planning of teachers' practical ability cultivation and training, and incorporate it into the overall planning of the teaching team construction. 
Put forward a clear objectives and tasks, establish a scientific training mechanism, take effective measures to develop a strong policy support, and effectively put the plan into effect. In the training mode, avoid the formalization and pay attention to the effect. Through the hierarchical classification, mentoring, going out, and letting come in and other various ways and channels to carry out the work.

\section{Policy and Guarantee of Promoting the Development of College Teachers' Practical Ability}

\subsection{Reform the Current Teacher Professional Title Evaluation System}

Reform the widely existing defects of Colleges and universities teachers title evaluation of "the unified", "academic" and so on. In the evaluation of professional titles, it should also guide and require in different classification. The first one is that the working conditions for various Colleges and universities at all levels of professional titles for teachers should have clear requirements on practice ability and level of the corresponding post. Take it necessary condition for review that the whether to assume practical teaching activities, whether have the corresponding post practice experience and so on; secondly, add application achievement requirements of a number of disciplines and professionals on the practical innovation ability and level; the third one is the establishment of professional title evaluation system and methods service on the cultivation of applied talents, to promote applied talents training Colleges and universities to achieve "double qualified" of teacher team. In short, through policy orientation of the assessment conditions, guide teachers to improve the level of practical education and practical ability.

\subsection{Establish an Effective Incentive Mechanism}

Strengthen the assessment of teachers to engage in the practice of teaching and participate in the training of the ability, such as in the annual assessment, increase qualitative and quantitative assessment content like assuming the training and guidance of practice teaching and so on; for the teachers who do not complete the prescribed tasks of practice teaching, or do not participate in the provision of practical training project, depending on the circumstances, defer employment or low hire. Establish reward system at the same level of research and teaching achievements. Give strong recognition award for the teachers who have made important achievements in the practice of teaching activities, research cooperation and cooperation in education and who make outstanding contributions [7]. In the meanwhile, in the workload evaluation and remuneration payable aspect, it is also necessary to guarantee in the system, encourage teachers to actively participate in all kinds of practical teaching activities, be willing to take exercise with hanging duty in enterprise, and actively participate in the cooperation of production, teaching and research.

\subsection{Introduce Policies and Regulations to Promote the Cooperation of Industry, University and Research}

That enterprises generally are not willing to receive College students to practice has always been a difficult problem for the schools to carry out professional practice teaching activities. The government is supposed to take the possible administrative intervention or policy support, such as use preferential policies like tax relief and other incentives to encourage enterprises to accept students to practice, so as to help Colleges and universities to establish a stable practice teaching base. In the case of cooperation of industry, university and research institute is often "a single hot", government and the legislature department should also play its due role, such as the development of relevant laws and administrative rules and regulations, establish cooperation promotion law, through legislation to promote research party's initiative cooperation, urge the parties to fulfill their obligations, and make cooperation truly become the need of various parties. 


\section{Conclusion}

Face the problems that practical ability of teachers in Colleges and universities in our country is low, and problems existing in educational practice, independent development, scientific research and participation in enterprise practice capacity and so on, we need to introduce teachers through many ways and a variety of channels; strengthen school-enterprise cooperation, and improve teachers' practical ability; make development planning and establish a training system to comprehensively improve the practical ability of College teachers. In the meanwhile, it is also supposed to give full play to the role of policy orientation, such as to reform the current teachers title evaluation system, establish an effective assessment and incentive mechanism, and introduce policies and regulations to promote the cooperation of production, teaching and research, effectively facilitate the development of teachers' practical ability in Colleges and universities [8]. Only in this way can it be possible to cultivate applied talents with strong practical ability, so as to promote the better development of professionals, make the Colleges and universities better adapt to the needs of the development of the industry, which is the fundamental of the survival and development for Colleges and universities.

\section{References}

[1] Richter D, Kunter M, and Klusmann U. Professional development across the teaching career [M] Teachers' professional development. SensePublishers, 2014: 97-121.

[2] Desimone L M, Garet M S. Best practices in teachers' professional development in the United States [J]. Psychology, Society and Education, 2015, 7(3): 252-263.

[3] Roeser R W, Skinner E, and Beers J. Mindfulness training and teachers' professional development: An emerging area of research and practice [J]. Child Development Perspectives, 2012, 6(2): 167-173.

[4] Matzat U. Do blended virtual learning communities enhance teachers' professional development more than purely virtual ones? A large scale empirical comparison [J]. Computers \& Education, 2013, 60(1): 40-51.

[5] Van Driel J H, Berry A. Teacher professional development focusing on pedagogical content knowledge [J]. Educational Researcher, 2012, 41(1): 26-28.

[6] Twining P, Raffaghelli J, and Albion P. Moving education into the digital age: the contribution of teachers' professional development [J]. Journal of Computer Assisted Learning, 2013, 29(5): 426-437.

[7] Garet M S, Porter A C, and Desimone L. What makes professional development effective? Results from a national sample of teachers $[\mathrm{J}]$. American educational research journal, 2001, 38(4): 915-945.

[8] Butler D L, Lauscher H N, and Jarvis-Selinger S. Collaboration and self-regulation in teachers' professional development [J]. Teaching and teacher education, 2004, 20(5): 435-455. 